\title{
Summary: The Budapest Meeting 2005 Intensified Networking on Ethics of Science
} The case of Reproductive Cloning, Germline Gene Therapy and Human Dignity

Guido Van Steendam, András Dinnyés, Jacques Mallet, Rolando Meloni, Carlos Romeo Casabona, Jorge Guerra González, Josef Kuře, Eörs Szathmáry, Jan Vorstenbosch, Péter Molnár, David Edbrooke, Judit Sándor, Ferenc Oberfrank, Ron Cole-Turner, István Hargittai, Beate Littig, Miltos Ladikas, Emilio Mordini, Hans E. Roosendaal, Maurizio Salvi, Balázs Gulyás, Diana Malpede*

\section{Announcement and call for input}

The text below is part of a process that you are invited to join. The text is the introduction to a longer article that summarizes the discussions during a meeting of coordinators of EU funded projects in ethics of science and engineering. The meeting took place in Budapest in November 2005. The first version of the full article is online on \{www.opragen.co.uk (Science and Engineering Ethics)\} and on www.embeddingethics.net.

The second version of this summary article will be published in the October 2006 issue of Science and Engineering Ethics. While the first version does not contain bibliographic references, in the second version notes and bibliographic references will be added, including references to publications and websites of the many EU funded projects and of other original research that is already mentioned in the summary article.

The authors would welcome reactions from researchers who submit references to their own work that either expands some of the points that are already mentioned in the article or that develops alternative approaches. Researchers are invited to add short comments of up to 15 words. The authors will edit and group contributions and make a selection when references or comments overlap.

Contributions can be sent to Guido Van Steendam:

guido.vansteendam@biophilosophy.be.

* For more information about the authors and the participants in the Budapest Meeting, see pp. 419420 .

Address for correspondence: Guido Van Steendam, Director, International Forum for Biophilosophy, Craenendonck 15, B-3000 Leuven, Belgium; guido.vansteendam@biophilosophy.be.

2006, Published by Opragen Publications, POB 54, Guildford GU1 2YF, UK. http://www.opragen.co.uk 
There is a goldmine of information, creativity and researcher enthusiasm just waiting to be tapped in the many EU-funded projects relating to the ethics of science. Coordinators of relevant projects are exploring possibilities to increase the value of these resources through structured interactions.

The process started at a meeting organized by the EU Reprogenetics project that took place in Budapest on November 6-9, 2005. Reprogenetics is an EU funded project that started in 2004 and will end in 2007. The project is studying the ethical aspects of two controversial issues: the use of human cloning as a means for reproduction (often called "human reproductive cloning") and the use of human gene therapy, which involves making a genetic correction that is transmitted to subsequent generations (often called "human germline gene therapy"). Both technologies are currently banned.

The Reprogenetics research team believed that they would learn a lot from the experience and input of other EU funded projects that were investigating similar or complementary issues, or using similar methodologies. This is why the Reprogenetics team organized a Sounding Board meeting in Budapest and invited a large group of EU project coordinators to discuss the major topics with them. During the many formal and informal discussions, the Reprogenetics researchers learned much more than they had ever hoped. The invited coordinators and research leaders of other projects had a similar experience. They found out that they are not sufficiently aware of the results of other projects and that a structured interaction between ongoing projects could have a major impact on their own work and results.

Following the Budapest Meeting, initiatives were taken to explore the possibility of organizing regular contacts and of preparing regular overviews of what is going on in EU projects. Participants who could not attend the Budapest Meeting endorsed the initiative to find ways to keep the momentum alive. The possibilities were also discussed with the European Commission, the World Science Forum and the Science Policy Division of UNESCO.

During a Workshop in Brussels on March 17-19, 2006, a group of EU researchers, international experts, the World Science Forum and UNESCO endorsed the plans to develop a new annual series of 'The Budapest Meeting'. This meeting will take place in a European city and will make a contribution to the events of the World Science Day for Peace and Development organized by UNESCO every year on November $10^{\text {th }}$. It will also make a contribution to the World Science Forum, which is organized every two years in Budapest as a major event of the World Science Day.

This article provides a summary of the discussions that took place during the Budapest Meeting and it explains the subsequent networking that has grown up around this event. This summary article is divided into five parts:

\section{Context of the Budapest Meeting}

(1) The Objectives of the Reprogenetics project

(2) Preliminary Conclusions

(3) Sounding Board

2. Interaction Sessions on the Topics in Focus:

(1) Reproductive Cloning. The world in 2025 
(2) Germline Gene Therapy. The world in 2025

(3) The United Nations and Human Dignity

3. Interaction Sessions on Ethical Values in Context

(1) Clinical testing and hospital care

(2) Ambient Intelligence, computers and nanotechnology

(3) Nature, animals and food

(4) Brain research and dementia

(5) Old age, Intensive Care Units and death

4. Interaction Sessions on Ethical Decision-Making

(1) Do we need intercontinental collaboration?

(2) Does the integration of the EU's New Member States require specific action?

(3) Is there a role for the religious traditions?

(4) Is there a role for the media and the general public?

(5) Can stakeholders speak a common ethical language?

5. Outcomes

(1) Conclusions and Recommendations of the Sounding Board

(2) World Science Forum

(3) A new annual series of "The Budapest Meeting"

1. Context of the Budapest Meeting provides basic information about the objectives and preliminary conclusions of the Reprogenetics project and about the initial plans to organize a sounding board. The Reprogenetics project is studying the widely endorsed conviction that human reproductive cloning and human germline gene therapy should be permanently banned for ethical reasons. The aim of the project is to determine the extent to which such an "ethical ban" can have an impact on the daily scientific practice of the researchers involved or, in general, how ethical reflection, debate and regulation should be organized to optimize their impact on the ethics embedded in scientific practice.

The case of reproductive cloning and germline gene therapy presents many challenges. There appears to be a disproportion between the strength with which the ban is imposed and the strength - or rather the weakness and vagueness - of the arguments put forward to justify it.

Even researchers who would be willing to unconditionally respect an absolute ban imposed by society, cannot always know exactly which research or clinical procedures are banned and which procedures are allowed or even encouraged.

2. Topics in Focus is a more detailed report on the first three Interaction Sessions that took place during the Budapest Meeting. Each session focused on one of the three Topics in Focus that were selected by the Reprogenetics project.

Interaction Sessions (1) and (2) dealt with the research scenarios and plans that are currently being drawn up in the world of cloning and gene therapy. It turned out that the difficulty of linking ethics and science in a clear way may in part be due to the fact that the scientific research itself is not so straightforward as the ethicists, lawmakers or 
society at large often assume. For example, while the distinction between "reproductive cloning" and "therapeutic cloning" is widely known among ethicists, in scientific practice the cluster of different cloning procedures and scenarios is much more complicated and is continuously evolving. Contrary to common belief, if an adult person were to be cloned, the clone would not just be a look-alike. Moreover, cloning would be a reproductive tool not only for single people, but also for couples, whereby both father and mother would contribute in an equal way to the genetic makeup of the child. Furthermore, while it is convenient for ethicists and politicians to distinguish between different fields of activity such as cloning, gene therapy, stem cell research and fertility research, in scientific practice they overlap and intermingle. Contemporary scenarios for gene therapy make use of cloning and embryonic stem cells. Some fertility treatments already apply genetic corrections that will be transmitted to subsequent generations. The news of such pioneering treatments did not shock society, even though they can be classified as "germline gene therapy". Interaction Session (3) addressed the notion of Human Dignity in a recent Declaration by the United Nations that issued a ban on reproductive cloning. This session dealt with the problem that the notion of "Human Dignity" as it is used in this Declaration would never work as a basis for scientists to determine what society wants them to ban, and what society would allow or even encourage them to do.

At the organizational level, this first series of Interaction Sessions resulted in the conclusion that a network for structural collaboration between EU projects in ethics is urgently needed, and that such a network should include structural links to projects in the so-called "hard sciences".

3. Ethical values in context summarizes the discussions on EU funded research projects in five different social and scientific contexts: (1) Clinical testing and hospital care, (2) Ambient Intelligence, computers and nanotechnology, (3) Nature, animals and food, (4) Brain research and dementia, (5) Old age, Intensive Care Units and death. These five fields were selected because in the general literature they are intimately linked with the notion of Human Dignity, which plays a central role in the ethical ban that the Reprogenetics project is studying. For each field, a separate Interaction Session was organized. During each session, the participants were asked to identify the major ethical issues involved in the field and the approaches developed in the relevant EU projects. They were also asked to indicate the extent to which the notion of Human Dignity played a role in the project. As to this last question, most projects did not go further than the tacit assumption or formal acknowledgment that scientific practice should not run counter to the principle of Human Dignity. Only one project ("Dignity and Older Europeans") explicitly used the notion to clarify the ethical issues at hand.

At the organizational level, each session revealed that several projects were doing similar work or were using similar notions, and that the different teams could learn a lot from the intermediate results and methodological decisions of the others. There was a growing conviction that it would be in the interest of all parties concerned if the interaction were not dependant on accidental collaboration or meetings, but were rather organized in a structural and permanent manner. 
4. Ethical decision-making summarizes the discussions on methodological questions linked to the organization of ethical reflection and debate. Five questions were addressed: (1) Do we need intercontinental collaboration? (2) Does the integration of the EU's New Member States require specific action? (3) Is there a role for the religious traditions? (4) Is there a role for the media and the general public? (5) Can stakeholders speak a common ethical language? For each question, one specific Interaction Session was organized. In each of the sessions (1) to (4), the group endorsed the need to establish strong links with the social actors under study, and explored the limits and possibilities of such interaction. Session (5) endorsed the suggestion that it would be wrong to believe that "open and constructive exchange of information" is only possible when all partners involved use the same words in exactly the same sense. The group emphasized that the most important prerequisite for "speaking the same language" is the structural context and the attitude of mind in which people feel that they are developing and implementing common goals.

At the organizational level, the sessions resulted in the conclusion that a strong operational network should not only organize structural links between EU projects in ethics and EU projects in the so-called hard sciences, but that it should also develop strong links with leading programs worldwide, with the religious traditions and with lay people. Furthermore, special attention must be paid to capacity building in the EU's New Member States. Without ignoring the importance of clear language, the goal of the network should not be to develop a merely verbal consensus, which may be devoid of real communication, but rather to develop a pluralist platform of collaboration in an effort to exchange information, to allow the participants to clarify their own assumptions and to develop common approaches and common goals whenever possible.

5. Outcomes summarizes the conclusions of the sounding board, the links with the World Science Forum and the plan to develop a new annual series of "The Budapest Meeting".

\section{* The authors of the summary article:}

Guido Van Steendam (IFB, Leuven, Belgium),

András Dinnyés (Department of Animal Biology, Agricultural Biotechnology Center in Gödöllö,

Hungary),

Jacques Mallet (CNRS, National Center for Scientific Research, Paris, France),

Rolando Meloni (CNRS, National Center for Scientific Research, Paris, France),

Carlos Romeo Casabona (Inter-University Chair in Law and the Human Genome, Deusto and University of the Basque Country, Bilbao, Spain),

Jorge Guerra González (Inter-University Chair in Law and the Human Genome, Deusto and University of the Basque Country, Bilbao, Spain),

Josef Kuře (University Centre for Bioethics, Masaryk University, Brno, Czech Republic),

Eörs Szathmáry (Collegium Budapest, Budapest, Hungary),

Jan Vorstenbosch (Ethics Institute, Utrecht University, Netherlands).

Péter Molnár (Medical and Health Sciences Centre, University of Debrecen, Debrecen, Hungary),

David Edbrooke (Intensive Care Medicine, Royal Hallamshire Hospital, Sheffield, UK), 
Judit Sándor (Center for Ethics and Law in Biomedicine, Central European University, Budapest, Hungary),

Ferenc Oberfrank (KOKI, Institute of Experimental Medicine, Hungarian Academy of Sciences, Budapest, Hungary),

Ron Cole-Turner (Pittsburgh Theological Seminary, Pittsburgh, USA),

István Hargittai (University of Technology and Economics, Budapest, Hungary),

Beate Littig (Department of Sociology, the Institute for Advanced Studies, Vienna, Austria),

Miltos Ladikas (Centre for Professional Ethics, University of Central Lancashire, Preston, UK),

Emilio Mordini (Centre for Science, Society and Citizenship, Rome, Italy),

Hans E. Roosendaal (NIKOS, Dutch Institute for Knowledge Intensive Entrepreneurship, University of Twente, Enschede, Netherlands),

Maurizio Salvi (Brussels, Belgium),

Balázs Gulyás (Executive Director, World Science Forum; Department of Clinical Neuroscience, Karolinska Institute, Stockholm, Sweden),

Diana Malpede (Science Policy Division, UNESCO, Paris, France).

\section{Researchers in charge of the Reprogenetics project:}

Paolo De Nardis (Rome), John Harris (Manchester), Matthias Kaiser (Oslo), Jacques Mallet (Paris), Ferenc Oberfrank (Budapest), Carlos Romeo Casabona (Bilbao), Guido Van Steendam, coordinator (Leuven).

\section{Participants in meetings to prepare The Budapest Meeting 2005}

Jean-Michel Baer (Brussels), David Edbrooke (Sheffield), Balázs Gulyás (Stockholm), Norbert Kroo (Budapest), Emilio Mordini (Rome), Ferenc Oberfrank (Budapest), Hans Roosendaal (Enschede), Maurizio Salvi (Brussels), Judit Sándor (Budapest), Guido Van Steendam (Leuven).

\section{Participants in The Budapest Meeting 2005 (Budapest, 6-9 November 2005)}

Espen Brandshaug (Oslo), Astrid Cocozza (Oslo), Christian Coff (Copenhagen), Ron Cole-Turner (Pittsburgh), Katelijne Contreras (Brussels), Meredith Crosby (Cleveland), Borja de Arana (Bilbao), Tanja De Coster (Brussels), Iñigo de Miguel Beriain (Bilbao), Paolo De Nardis (Rome), András Dinnyes (Gödöllö), David Edbrooke (Sheffield), Torunn Ellefsen (Oslo), Aitziber Emaldi Cirión (Bilbao), Bert Gordijn (Nijmegen), Jorge Guerra (Bad Neuenahr-Ahrweiler), Balázs Gulyás (Stockholm), István Hargittai (Budapest), Colin Harper (Belfast), François Hirsch (Paris), Matthias Kaiser (Oslo), Morten Kjerstad Larsen (Oslo), Josef Kuře (Brno), Miltos Ladikas (Preston), Beate Littig (Vienna), Ana María Marcos (Madrid), Rolando Meloni (Paris), Anton Mlinar (Ljubljana), Kristine Mjølnes (Oslo), Péter Molnár (Debrecen), Fruzsina Molnár-Gábor (Budapest), Maria Nastac (Constanta), Kevin Yana Njabo (Boston), Ferenc Oberfrank (Budapest), Solvita Olsena (Riga), Michal Pálka (Banská Štiavnica) Valdar Parve (Tartu), Eimantas Peicius (Kaunas), Marie Hélène Pinard-Van der Laan (Paris), Aurora Plomer (Nottingham), Carlos Romeo Casabona (Bilbao), Maurizio Salvi (Brussels), Judit Sándor (Budapest), Alessandra Sannella (Rome), Daniel Sinclair (Jerusalem), Guadalupe Soria (Barcelona), Bella Starling (London), Peter Sykora (Bratislava), Eörs Szathmáry (Budapest), Imre Szebik (Budapest), Winfred Tadd (Cardiff), Els Van den Cruyce (Brussels), Tine Vandensande (Brussels), Guido Van Steendam (Leuven), Jan Vorstenbosch (Utrecht), Harry Wagenvoort (Leuven), Zbigniew Zalewski (Krakow).

\section{Participants in the follow up Workshop (Brussels, 17-19 March 2006)}

Daniel Callahan (New York), Jean Pierre Changeux (Paris), Katrien De Volder (Gent), David Edbrooke (Sheffield), Eric Juengst (Cleveland), Eugenijus Gefenas (Vilnius), Balázs Gulyás (Stockholm), Josef Kuře (Brno), Diana Malpede (Paris), Rasto Marko (Banská Štiavnica), Fruzsina Molnár-Gábor (Budapest), Michal Pálka (Banská Štiavnica), Patricia Powers (Cleveland), Hans Roosendaal (Enschede), Daniel Sinclair (Jerusalem), Imre Szebik (Budapest), Tine Vandensande (Brussels), Guido Van Steendam (Leuven), René von Schomberg (Brussels), Harry Wagenvoort (Leuven). 